\title{
The Landscape of Actionable Gene Fusions in Colorectal Cancer
}

\author{
Filippo Pagani ${ }^{1}$, Giovanni Randon ${ }^{1}$, Vincenzo Guarini ${ }^{1}$, Alessandra Raimondi ${ }^{1}$, \\ Michele Prisciandaro ${ }^{1}$, Riccardo Lobefaro ${ }^{1}$, Maria Di Bartolomeo ${ }^{1}$, Gabriella Sozzi ${ }^{2}$, \\ Filippo de Braud ${ }^{1,3}$, Patrizia Gasparini ${ }^{2,+}$ (D) and Filippo Pietrantonio $1,3, *,+[D$ \\ 1 Medical Oncology Department, Fondazione IRCCS Istituto Nazionale dei Tumori, 20133 Milano, Italy; \\ filippo.pagani@istitutotumori.mi.it (F.P.); giovanni.randon@istitutotumori.mi.it (G.R.); \\ vincenzo.guarini@istitutotumori.mi.it (V.G.); alessandra.raimondi@istitutotumori.mi.it (A.R.); \\ michele.prisciandaro@istitutotumori.mi.it (M.P.); riccardo.lobefaro@istitutotumori.mi.it (R.L.); \\ maria.dibartolomeo@istitutotumori.mi.it (M.D.B.); filippo.debraud@istitutotumori.mi.it (F.d.B.) \\ 2 Unit of Molecular Cytogenetics, Fondazione IRCCS Istituto Nazionale Tumori, 20133 Milano, Italy; \\ gabriella.sozzi@istitutotumori.mi.it (G.S.); patrizia.gasparini@istitutotumori.mi.it (P.G.) \\ 3 Department of Oncology and Hemato-Oncology, University of Milan, 20122 Milan, Italy \\ * Correspondence: filippo.pietrantonio@istitutotumori.mi.it \\ $\dagger$ These authors contributed equally to this work.
}

Received: 17 September 2019; Accepted: 23 October 2019; Published: 25 October 2019

\begin{abstract}
The treatment scenario of metastatic colorectal cancer (mCRC) has been rapidly enriched with new chemotherapy combinations and biological agents that lead to a remarkable improvement in patients' outcome. Kinase gene fusions account for less than $1 \%$ of mCRC overall but are enriched in patients with high microsatellite instability, RAS/BRAF wild-type colorectal cancer. mCRC patients harboring such alterations show a poor prognosis with standard treatments that could be reversed by adopting novel therapeutic strategies. Moving forward to a positive selection of $\mathrm{mCRC}$ patients suitable for targeted therapy in the era of personalized medicine, actionable gene fusions, although rare, represent a peculiar opportunity to disrupt a tumor alteration to achieve therapeutic goal. Here we summarize the current knowledge on potentially actionable gene fusions in colorectal cancer available from retrospective experiences and promising preliminary results of new basket trials.
\end{abstract}

Keywords: gene fusions; colorectal cancer; translocation; biomarker

\section{Introduction}

Colorectal cancer represents the third most common tumor in men and the second in women, with an estimated incidence of approximately 1.8 million new cases and a total number of about 860,000 deaths worldwide in 2018 [1]. The treatment landscape of $\mathrm{mCRC}$ has undergone a dramatic change in the last decades, allowing to reach a remarkable improvement in patients' prognosis, thanks to the introduction of biological agents (anti-angiogenic and anti-Epidermal Growth Factor Receptor (EGFR)) [2] and the development of continuum of care strategies across several available treatment options [3,4]. Nowadays, the decision-making process on the optimal treatment approach in mCRC patients should carefully consider both the patients' characteristics and the tumor's molecular profile [5]. Specifically, all the major guidelines recommend the testing of the mutational status of RAS and BRAF genes [6,7] since $R A S$ mutation is a validated negative predictive marker for anti-EGFRs response, and BRAF V600E mutations are associated with a very limited benefit from EGFR inhibitors [8].

Nevertheless, the recent progress in tumor genomic profiling has shed light on the complex molecular scenario of mCRC [9], identifying a wide range of genomic alterations (mutations, translocations, or amplifications) that could play both a prognostic role, conferring a higher 
aggressiveness to the tumor, and a predictive one, identifying tumors with primary refractoriness to biologic agents, with the aim to better select patients for the different treatment options $[10,11]$. Moving forward, the new molecular aberrations identified may constitute a driver for tumor initiation and progression, thus potentially representing new therapeutic targets, allowing to reach a deeper treatment personalization.

In this setting, the emerging role of genomic translocations has to be emphasized. Gene fusions represent an important piece of the puzzle of the tumor genomic landscape and are involved in the development of about $16 \%$ of all cancer types [12]. In fact, in some cases, they display a close correlation with a specific tumor subtype, thus representing a diagnostic marker (e.g., FLI1/EWS in Ewing Sarcoma), while in others they are endowed with a prognostic value, providing a risk stratification (e.g., the presence of gene fusions in embryonal rhabdomyosarcoma), or they could represent a potential therapeutic target (e.g., $A L K$ and ROS1 in non-small cell lung cancer (NSCLC)) [13]. In the last decades, an increasing number of gene rearrangements has been identified in several cancer types, including CRC, thanks to new techniques of high-throughput genome sequencing, although the available body of knowledge on gene fusions in tumors is still incomplete [14]. Specifically, the key challenge is to distinguish the genomic aberrations that represent true oncogenic drivers from the passenger alterations that do not play a role in the cancer development and progression. Potential distinction factors could be the biological function of the genes involved and the type of rearrangement (juxtaposition to the promoter of a highly-expressed gene or the presence of a continuous open reading frame with functional domains, such as kinases) [15].

However, the low frequency of the singular novel genomic alterations and gene fusions is a limiting factor for their thorough study from a pathogenic and therapeutic perspective, hampering the investigation in dedicated clinical trials and the translation in the clinical practice setting [16]. In this light, the paradigm of cancer research is undergoing a deep change: from a tumor type-focused approach to a molecularly-directed agnostic one, exploring the role of biologic agents targeted to the driver genomic alteration irrespectively of the cancer histology [12]. Thanks to the recently-conducted basket trials, clinical studies in which patients affected by several tumor types harboring the same genomic aberration received a specific targeted treatment, the tyrosine kinase inhibitor (TKI) larotrectinib was granted accelerated approval by Food and Drug Administration (FDA) for cancers displaying NTRK pathogenic fusions while entrectinib, a TKI targeting NTRK, ALK and ROS1 fusions, was granted priority review by FDA $[17,18]$.

Besides this tissue-agnostic approach, the deep understanding of the genomic profile of the singular tumor types is still crucial in order to identify subgroups of patients with an enrichment of peculiar molecular drivers and to better select the optimal candidates for genomic testing and targeted treatment. Specifically, in CRC, a recent comprehensive analysis of 2.314 cases showed how the frequency of kinase gene fusions in an unselected population is about $0.9 \%$, but it significantly increases in MSI-high (MSI-H) tumors (5\%) and overall in RAS/BRAF wild type cancers (15\%) [19]. Preclinical data and translational studies have shown the potential importance of the identification of patients affected by tumors harboring molecularly altered kinase genes, since they represent a population unlikely to respond to anti-EGFR treatment but may benefit from selective targeted agents [20,21]. However, further studies are warranted to validate this evidence through prospective, ad-hoc-designed clinical trials and to potentially change the treatment paradigm in these selected populations.

In this review we aim at summarizing the available literature evidence on the genomic fusions in CRC, with a specific focus on those harboring a prognostic and/or predictive value or especially representing potentially druggable targets in the metastatic disease setting.

\subsection{NTRK}

Neurotrophic receptor tyrosin kinase genes NTRK-1, NTRK-2, NTRK-3 (encoding for TRK-A, TRK-B, and TRK-C respectively) are involved in neuronal tissue homeostasis and expression is mainly confined to the nervous system in adult tissues. Ligands include neurotrophins such as NGF 
(for TRK-A), BDNF and NF4 (for TRK-B) and NT3 (for TRK-C) [22]. Fusions account for the most common oncogenic activation of NTRK genes and are found at a low frequency in colorectal cancer (i.e., around $0.9 \%$ ) [23].

The presence of NTRK fusions may be shown by extended next-generation sequencing, targeted RNA sequencing, and fluorescent in situ hybridization, while immunohistochemistry (IHC) is performed as a screening method to detect the overexpression of any TRK receptor (A, B, or C), a result that reflects the gene fusion. Whilst IHC may represent a rapid and costless screen for NTRK fusions endowed with high specificity [24,25], caution should be taken for MSI-H CRC tumors as mutations within the epitope recognized by pan-TRK antibody might impair specificity of the assay [26].

In CRC, NTRK fusions (Table 1a) are associated with female gender, elderly age, right sidedness, lymph node metastatic spread, MSI-H, and RAS and BRAF wild-type status as well as dismal prognosis with median overall survival (OS) of around 15 months in the metastatic setting [27]. Beyond bearing a well-defined prognostic role NTRK fusions are likely to account for primary resistance to EGFR targeted agents [21] due to downstream mitogen-activated kinases (MAPKs) activation [28].

Table 1. (a) Potentially actionable gene fusions in CRC. (b) Not yet actionable gene fusions in CRC.

\begin{tabular}{|c|c|c|c|c|c|c|c|c|c|c|}
\hline \multicolumn{11}{|c|}{ (a) } \\
\hline \multirow{19}{*}{$\begin{array}{l}\text { Fusion } \\
\text { Partners }\end{array}$} & NTRK1- & NTRK2- & NTRK3- & ALK- & ROS1- & RET1- & BRAF- & FGFR2- & FGFR3- & ERBB2- \\
\hline & LMNA & \multirow{18}{*}{$\begin{array}{c}\text { DAB2IP } \\
\text { [29] }\end{array}$} & \multirow{18}{*}{$\begin{array}{c}\text { ETV6 } \\
{[29]} \\
\text { EML4 } \\
{[16]} \\
\text { KANK1 } \\
{[31]}\end{array}$} & SPTBN1 & GOPC & CCDC6 & AGAP3 & \multirow{18}{*}{$\begin{array}{c}\text { MYH15 } \\
\text { [19] }\end{array}$} & STAB1 & \multirow{18}{*}{$\begin{array}{c}\text { GRB7 } \\
\text { [30] }\end{array}$} \\
\hline & & & & & & & [19] & & [19] & \\
\hline & TPM3 & & & CAD & SLC34A2 & GEMIN5 & TRIM24 & & SPDYE4 & \\
\hline & SCYI3 & & & FMI 4 & & $\begin{array}{c}{[19]} \\
\mathrm{NCOA4}\end{array}$ & {$[19]$} & & & \\
\hline & [29] & & & $\begin{array}{l}\text { EML4 } \\
{[27]}\end{array}$ & & $\begin{array}{c}\text { NCOA4 } \\
\text { [19] }\end{array}$ & $\begin{array}{l}\text { CUL1 } \\
\text { [19] }\end{array}$ & & & \\
\hline & PLEKHA6 & & & CENPF & & RUFY1 & MKRN1 & & & \\
\hline & [29] & & & [27] & & [31] & [19] & & & \\
\hline & & & & PRKAR1B & & TNIP1 [27] & ARMC10 & & & \\
\hline & & & & [27] & & TNIPI [27] & [31] & & & \\
\hline & & & & MAPRE3 & & SNRNP70 & AKAP9 & & & \\
\hline & & & & [27] & & [27] & [31] & & & \\
\hline & & & & STRN [27] & & & & & & \\
\hline & & & & C2orf44 & & & & & & \\
\hline & & & & [32] & & & & & & \\
\hline & & & & PPP1R21 & & & & & & \\
\hline & & & & [33] & & & & & & \\
\hline & & & & SMEK2 & & & & & & \\
\hline & & & & [34] & & & & & & \\
\hline
\end{tabular}

(b)

\begin{tabular}{cc}
\hline Gene Fusions \\
\hline ERAS-USP9X [16] \\
RSPO2-EIF3E [16] \\
RSPO3-PTPRK [16] \\
NCOA2-LACTB2 [15] \\
TCF7L2-VTI1A [15] \\
TCF7L2-RP11-57A14.3 [15] \\
SARAF (TMEM66)-NRG1 [35] \\
GTF3A-CDK8 [36] \\
NAGLU-IKZF3 [36] \\
RNF121-FOLR2 [36] \\
NFATC3-PLA2G15 [37]
\end{tabular}

Several NTRK-targeted TKIs are at different stages of clinical development, or TKI with anti-TRK activity are available whose labeling is limited to different indications than treatment of NTRK fusion positive tumors (Table 2) [22]. The oral TRK-selective inhibitor larotrectinib was granted tissue-agnostic FDA approval on November 2018 based on results of single-arm trials LOXO-TRK-14001, SCOUT and NAVIGATE [18]. Among 55 treated patients, including 4 patients with metastatic CRC (mCRC), objective response rate was as high as $75 \%$; in the latter group RECIST partial response and disease 
control rate were achieved in 2 and 4 cases, respectively. Clinical benefit was seen regardless of specific NTRK fusion partner. Entrectinib is an oral inhibitor of NTRK, ALK, and ROS1 [38]. Entrectinib has been tested in the single-arm trials ALKA-372-001, STARTRK-1 [39], STARTRK-02 [40], and STARTRK-NG [41]. Among treated patients with NTRK-fusion positive tumors, 1 was diagnosed with a LMNA-NTRK1 rearranged $\mathrm{mCRC}$ and achieved a 12-week lasting partial response.

Table 2. Approved drugs in solid tumors with known activity against recurrent mCRC gene fusions.

\begin{tabular}{cccc}
\hline Gene Fusion & Drug & Disease & References \\
\hline \multirow{2}{*}{ NTRK1,2,3- } & Entrectinib & Solid tumors & {$[39-41]$} \\
& Larotrectinib & Solid tumors & {$[18]$} \\
\hline & Crizotinib & NSCLC & {$[42]$} \\
& Entrectinib & NSCLC & {$[39-41]$} \\
ALK- & Alectinib & NSCLC & {$[43]$} \\
& Brigatinib & NSCLC & {$[44]$} \\
& Ceritinib & NSCLC & {$[45]$} \\
& Lorlatinib & NSCLC & {$[46]$} \\
\hline \multirow{2}{*}{ ROS1- } & Crizotinib & NSCLC & {$[47]$} \\
& Lorlatinib & NSCLC & {$[46]$} \\
& Entrectinib & NSCLC & {$[39-41]$} \\
\hline & Cabozantinib & RCC & {$[44]$} \\
& Vandetanib & Thyroid cancer & {$[48]$} \\
& Lenvatinib & RCC, Thyroid cancer & {$[49,50]$} \\
& Sorafenib & RCC, HCC & {$[51,52]$} \\
& Alectinib & NSCLC & {$[43]$} \\
& Regorafenib & CRC & {$[53]$} \\
& BLU-667 ${ }^{*}$ & Solid tumors & {$[54,55]$} \\
& LOXO-292 ${ }^{+}$ & Solid tumors & {$[56]$} \\
\hline FGFR2,3- & Erdafitinib & Urothelial carcinoma & {$[57]$} \\
\hline
\end{tabular}

${ }^{*}$ Not approved, planned FDA submission 2020. ${ }^{+}$FDA breakthrough therapy designation.

Collectively these data suggest that extended screening in selected mCRC patients should be recommended as targeted therapies might improve the otherwise poor prognosis of patients with tumors bearing NTRK-fusions.

\subsection{ALK and ROS1}

Anaplastic lymphoma kinase $(A L K)$ and v-ros avian UR2 sarcoma virus oncogene homolog (ROS1) encode tyrosine kinases that are constitutive activated by fusion events leading to cellular transformation and promoting survival and proliferation through downstream signaling. Nearly 30 different ALK fusion protein partners have been described, with echinoderm microtubule-associated protein-like 4 (EML4) and nucleophosmin (NPM) being the most prevalent in NSCLC and anaplastic large cell lymphoma (ALCL) occurring in 3\% to $5 \%$ and more than $50 \%$, respectively [58]. CD74-ROS1 fusion gene have been reported as ROS1 most common rearrangement in NSCLC for approximately $1 \%$ [59]. Although ROS1 and ALK tyrosine kinase domains share significant homology and their genes rearrangements are mutually exclusive, both have similar clinicopathological characteristics with high prevalence in younger, non-smoking patients with adenocarcinoma histotype [58-60].

ALK and ROS1 rearrangements (enlisted in Table 1a) rarely have been also identified in mCRC using technologies based on fluorescence in situ hybridization (FISH) [61], exon array profiling [62], and next generation sequencing (NGS) $[14,33]$ performed on archival tumor specimens.

Two studies evaluated the presence of the classic ALK-EML4 fusion gene by FISH, in the absence of any enrichment strategy to improve the detection rate, without evidence of rearrangement in metastatic colorectal cancer patients ( 0 of 770 [63], 0 of 17 [33]). Other investigators that utilized 
immunohistochemistry (IHC) as screening strategy to identify $A L K$ rearrangements, found $0.44 \%$ to $2.4 \%$ IHC and subsequent FISH positive cases [20,34,64,65]. Additionally, new gene fusions who may be potentially responsive to target therapy were identified through NGS. Lipson et al. described one case of C2orf44-ALK fusion mCRC [32]; moreover, Ying et al. reported SPTBN1, a gene encoding for a cytoskeletal protein, as a potential $A L K$ fusion partner [66]. Recently we retrospectively collected 14 cases of CRC harboring ALK (11 cases) and ROS1 ( 3 cases) fusions, along with 13 CRC cases harboring NTRK fusion, comparing with a cohort of 319 patients not bearing rearrangements [27]. The main finding of our work was the identification of clinical features and molecular characteristics of patients with these rearranged tumors already listed in the previous section. Further two rearrangement-positive cases of ROS1 were also described by Aisner et al. (2/236), suggesting that ROS1 gene may also be activated by gene fusion in CRC [67].

To date, crizotinib, a small molecule ATP analogue inhibitor of ALK, ROS1, and MET, is approved by FDA, EMA, and AIFA for the treatment of patients with ALK or ROS1-positive NSCLC [42,47]. Further examples of ALK TKIs include alectinib, ceritinib, brigatinib, and lorlatinib; all binding the ATP-pocket of the ALK kinase domain differently, showing various profiles of inhibition [58]. Alectinib was approved by FDA, EMA, and AIFA as first line treatment for ALK positive NSCLC based on results of randomized phase III ALEX study comparing alectinib vs crizotinib [43]. Moreover, third generation inhibitor of ALK and ROS1 tyrosine kinases lorlatinib was approved for second- or third-line treatment of ALK-positive metastatic NSCLC [46]. Patients with solid tumors harboring ROS1, ALK, or NTRK1/2/3 molecular alterations could also benefit from treatment with entrectinib [39] (Table 2).

$A L K$ and ROS1 rearrangements are new molecular subgroup of poor prognosis mCRC whose recognition allows a proper tailored management. New targeted strategies may be a promising treatment to be further investigated.

\subsection{RET}

The rearranged during transfection (RET) gene, encodes for a single-pass transmembrane receptor tyrosine kinase (RTK) required for the development of neural and genitourinary tissues. Its signaling is mediated by the bound of soluble proteins of the glial cell line-derived neurotrophic factor (GDNF) family ligands (GFLs), such as neurturin, artemin, and persephin. RET is not able to bind GFLs, but it needs an additional co-receptor that is the GDNF family receptor- $\alpha$ (GFR $\alpha$ ). This complex mediates RET homodimerization, trans-autophosphorylation of tyrosine residues within the RET intracellular domains, and the subsequent activation of signal transduction cascades including the MAPK, PI3K, JAK-STAT, PKA, and PKC pathways [68].

Oncogenic activation of $R E T$, causing heritable and sporadic cancers, results of either activating point mutations or genomic rearrangements with the production of chimeric RET proteins that lead to its constitutive activation or through aberrant expression or activation of wild-type receptors. Rearrangements mostly involve the long arm of chromosome 10 with inversions or translocations of RET $3^{\prime}$ kinase domain encoding sequences, with the $5^{\prime}$ - ones from several partner genes which encode protein dimerization domains. To date, more than 13 different $R E T$ translocations have been identified; however, those linking RET with the coiled-coil domain-containing 6 (CCDC6), nuclear receptor co-activator 4 (NCOA4), or with kinesin family member 5B (KIF5B) are the most reported $[68,69]$. CCDC6-RET and NCOA4-RET are the most commonly identified RET fusions in papillary thyroid cancers where RET rearrangements seem to be correlated with a more aggressive phenotype [70]. Otherwise, KIF5B-RET is the most commonly identified RET fusion in NSCLC associated with younger, never-smoker patients and poorly differentiated tumors [32,71,72].

RET fusions, although rare, are characteristic of a small subset of mCRC patients. Retrospective case series showed that RET rearrangements occurs in about the $0.2 \%$ of mCRC patients, and they are mutually exclusive with other driver mutations [73]. In a recently small series of $24 R E T$-rearranged mCRC patients, we observed that RET fusions were mainly NCOA4-RET and CCDC6-RET, while describing for the first time TNIP1-RET and SNRNP70-RET fusions. Moreover, we showed that RET 
fusions were more frequent in older patients, with Eastern Cooperative Oncology Group performance status (ECOG PS) 1-2, right-sided, unresected primary tumors, and they were associated with a significantly shorter OS when compared with 291 RET-negative patients (median OS 14.0 versus 38.0 months, HR: 4.59; 95\% CI, 3.64-32.66; $p<0.001$ ) [74]. Known RET partner genes are summarized in Table 1a.

Several multikinase inhibitor drugs showed activity against RET in preclinical and clinical studies [75]. Some of them have been approved by the FDA for the treatment of cancer (Table 2). In particular, cabozantinib [76], vandetanib [48], lenvatinib [49], and sorafenib [77] gained the approval for the treatment of medullary thyroid carcinomas and differentiated thyroid cancers while alectinib [43] has been approved in lung adenocarcinomas and regorafenib [53] in CRC. None of these drugs was designed to bind preferentially RET; for this, RET-specific antagonists are awaited to enrich the treatment armamentarium, to perform better clinical outcomes and to limit the consequences of the off-target toxicities caused by a multikinase inhibition, such as the adverse events (AEs) related to antiangiogenic activity [75]. Two small molecules with selective anti-RET activity, BLU-667 [78] and LOXO-292 [79], showed impressive results in preclinical models and are currently being evaluated in two ongoing basket trials, ARROW [80] and LIBRETTO-001 [81], respectively, that enroll patients with advanced, RET-altered solid tumors, that have progressed or are intolerant to available standard therapies. Preliminary results from 35 patients with RET-fusion positive tumors (27 NSCLC, 7 papillary thyroid cancer, 1 pancreatic cancer), treated with LOXO-292 showed a good tolerability, with none AEs graded $\geq 3$, and an overall response rate (ORR) of $69 \%$. NSCLC responses occurred independent of upstream partner when known [56]. Similar preliminary results have been achieved with BLU-667 in RET-fusion positive NSCLC [54] and thyroid cancer patients [55]. With respect to the mCRC patients' cohorts, unfortunately no data from clinical trials are currently available, but a case report of a patient with $\mathrm{mCRC}$ harboring a RET fusion treated with a selective RET inhibitor has been reported. The patient affected by a right sided, MSI-high, and CCDC6-RET positive mCRC achieved a complete response to the selective RET inhibitor drug RXDX-105 with an impressive PFS of 19 months [74]. Hope and confidence are rapidly growing around these new therapeutic options that could guarantee a great clinical benefit, although restricted to a small subset of patients.

\subsection{BRAF}

$B R A F$ gene encodes for a protein belonging to the RAF family of serine/threonine protein kinases. This protein plays a role in regulating the MAP kinase/ERK signaling pathway, which affects cell division, differentiation, and secretion. Activating oncogenic mutations in this gene, above all $\mathrm{V} 600 \mathrm{E}$, are encountered in a wide range of neoplasms and are mutually exclusive with mutations in KRAS/NRAS genes in mCRC [82]. Patients with BRAF V600E mutated mCRC derive limited benefit from standard therapies, have poor prognosis, and share peculiar clinical and pathological characteristics: they are frequently women with right-sided primary and mucinous histology [83]. Moreover, the presence of BRAF V600E mutation is frequently associated with a microsatellite instability status and spread to lymph nodes and peritoneum, characteristics that overlap those of mCRC enriched in gene fusions $[19,27,31,74]$.

Activating $B R A F$ gene fusions are the most prevalent genetic alteration in pediatric pilocytic astrocytoma [84] and are commonly detected in pediatric papillary thyroid carcinoma [85]. Acquisition of a $B R A F$ fusion has recently been described as a novel mechanism of acquired resistance to vemurafenib in a patient with BRAF V600E melanoma, underlining the key role of this oncogenic activation in cancer survival [86]. Furthermore, BRAF gene fusions have been detected in around $4 \%$ of skin melanoma without recurrent driver mutations in oncogenes, with preliminary evidences of response from MEK inhibitions [87].

Concrete efforts have been carried out in order to describe BRAF gene fusions in colorectal cancer (Table 1a). Ross et al. [88] analyzed 20,573 tumor samples, across 12 different kinds of solid tumors, and among them 2154 colorectal cancers, 4 of which $(0.2 \%)$ bearing BRAF translocations 
(1 AGAP3-BRAF and 1 MKRN1-BRAF in primary tumors; 2 TRIM24-BRAF, both in metastatic lesions). Both female and male patients were involved (53\% and $47 \%$ respectively), with a median age of 56 years [88]. Kloosterman et al. found among 278 primary colon cancer samples 3 different $B R A F$ gene fusions: AGAP3-BRAF and TRIM24-BRAF (caused by an inversion event) and DLG1-BRAF (deriving from a reciprocal translocation between chromosomes 3 and 7), all of them identified in wild-type $B R A F / K R A S / N R A S$ patients [16].

Unfortunately, no data are currently available on targeted therapy (e.g., with a MEK inhibitor agent) for patients with $B R A F$ rearranged $\mathrm{mCRC}$, underlining the urgent need to produce evidences supporting this novel therapeutic paradigm.

\subsection{Other Gene Fusions: An Emerging Complexity}

There are some subsets of colorectal tumors that express other gene fusions, some of which, however, are extremely rare or not yet therapeutically actionable (Table $1 \mathrm{~b}$ ).

Mutations and fusions in the gene encoding for the fibroblast growth factor receptor (FGFR2/3) are common in patients with urothelial carcinoma, accounting for around $20 \%$ in the advanced setting of the disease [89]. The treatment of patients affected by this tumor has been recently enriched by the small molecule erdafitinib, that received the FDA accelerated approval based on the results of a phase 2 study [57]. In mCRC, FGFR fusion are rare and occasionally reported (Table 1a) [19], but again, patients with $\mathrm{mCRC}$ harboring this specific alteration could benefit from a targeted treatment already available.

Selvam and colleagues evaluated gene fusions in 183 solid tumor samples by means of RNA sequencing [35]. In the CRC cohort of 18 cases, they identified two novel fusion gene transcripts, SARAF (TMEM66)-NRG1 and FGFR3-SPDYE4. In the same cohort the authors described two R-spondin fusions, EIF3E-RSPO2 and PTPRK-RSPO3, involving the R-spondin family members RSPO2 and RSPO3, already described by Seshagiri et al. [90] An ongoing phase I trial (NCT01351103) [91] is evaluating the dose escalation of oral LGK974 in patients with malignancies dependent on Wnt ligands. Another RNA sequencing study evaluating 147 CRC samples described 24 fusion gene transcripts, including novel fusions, 13 of which involved oncogenic fusions (e.g., GTF3A-CDK8, NAGLU-IKZF3, RNF121-FOLR2) whose overexpression correlates with cell proliferation [36]. Jang JE and colleagues performed RNA sequencing on 28 CRC cell lines describing a novel gene fusion transcript (NFATC3-PLA2G15) in two of them and demonstrating its contribution to tumor progression [37].

Human epidermal growth factor receptor 2 (HER2) is a member of the epidermal growth factor receptor (EGFR) family that activates subsequently to the heterodimerization with other ligand-bound receptors, such as HER3, triggering multiple downstream pathways, among which MAPK, PI3K-Akt are the main ones [92]. HER2 rearrangements are rare and reports are anecdotic. Ross et al. identified two patients one with lobular breast cancer and the other with urothelial bladder carcinoma with the ERBB2-GRB7 fusion subsequent to a deletion of an 18-kb segment on chromosome 17 [93,94]. The same fusion was also described by Chmielecki et al. in a bladder cancer and a breast cancer patient [95]. In all cases this rearrangement was mutually exclusive with other ERBB2 alterations. To our knowledge, only a HER2-rearranged mCRC sample as result of the same ERBB2-GRB7 fusion has been reported in the literature. A possible explanation of this lack of detection is that IHC testing for the fusion protein produces negative results due to the deletion of the IHC epitope in the altered protein, compromising a low-cost screening by this test. Unfortunately, the HER2-rearranged mCRC patient did not achieve a response from anti-HER2 therapies, but further evidences are needed to assess the functional and therapeutically significance of ERBB2 fusions [30]. Several HER2 inhibitors, such as trastuzumab, pertuzumab, and lapatinib, are routinely employed in the treatment of HER2 amplified breast and gastroesophageal cancers, and they might be active even in solid tumors with HER2 activating mutations [96]. Recently, an increasing consideration has been given to the oncogenic HER2 activation in CRC where its over-expression has been reported in $2 \%$ considering CRC overall, increasing up to $5 \%$ in stage III and IV KRAS exon 2 wild-type tumors [97-99]. HER2 gene amplification and HER2 activating mutations have been implicated as mechanisms for cancer cell resistance to 
anti-EGFR therapies in mCRC and, even if it is still debated, as negative prognostic biomarkers [100]. Furthermore, underlining the relevance of this oncogene activation in MCRC, the recent HERACLES and MYPATHWAY trials have established the clinical benefit in HER2 amplified mCRC patients treated with HER2 inhibitors [101,102]. HER2 fusions might be a potential target of inhibition; however, to date, there are not published or ongoing trials with HER2 inhibitors in patients with HER2-rearranged tumors.

\subsection{Methods to Detect Gene Fusions}

Fusion events, involving a variety of partner genes, result in the generation of chimeric fusion kinases with oncogenic transformation potential and induction of oncogene dependency within the neoplastic cells [103]. For all these reasons, their rapid and accurate detection can stratify cancer diagnosis and inform clinical action, while predicting prognosis, patient survival and treatment response [104].

Currently, conventional methods to detect clinically 'actionable' fusion genes in routine diagnostics rely on fluorescent in situ hybridization (FISH), immunohistochemistry (IHC), and/or quantitative real-time polymerase chain reaction (RT-PCR). While FISH, and at times IHC, is highly sensitive and considered the gold standard for several gene-testing (i.e., ALK), all these methods are low-throughput and typically only test for the presence of a single fusion gene, often resulting in a lengthy, tissue consuming, repetitive, and costly path to diagnosis [104,105]. As a consequence, only the recurrent fusion genes are iteratively tested during diagnosis [104]. Moreover, analysis and scoring systems of FISH signals as well as staining intensities of IHC require several skills and standard operating procedures in order to assure high-level quality of test results. These methods also rely on experienced and trained professionals, as FISH and IHC are challenged by subjective interpretations of results $[104,105]$. Another limitation to be considered is that neither FISH nor IHC provide information of the exact molecular breakpoints and, most of the times, cannot detect their partner genes. Indeed, defining the fusion partner gene is critical to refine treatment strategy, unveil the biology behind the genetic rearrangements and, most importantly, provide information on therapy response [105]. On the other hand, RT-PCR can overcome some of the issues presented by FISH and IHC, as it is a very sensitive method and the only one able to precisely detect fusions, including identification of both partner genes and the exons involved. However, RT-PCR is mainly focused on only the most frequent fusion events and cannot identify rare exon combinations. The great disadvantage of this methodology remains the limited multiplexing capability $[103,106]$.

In contrast to the traditional techniques, high-throughput transcriptome analysis and next generation sequencing (NGS) can deliver high-resolution fusion gene detection while assessing hundreds of genes in a single test, identifying both known and novel fusion genes (including rare fusions and novel gene partners) $[103-105,107,108]$. Several studies have provided evidence that these techniques not only provide the same sensitivity and specificity as conventional diagnostic methods but also rely on multiplexing potential, allowing to screen larger selection of actionable targets, with small amount of tissue sample $[19,103,108]$. The diagnostic power and the ability of targeted RNA-seq to identify different fusion genes as compared to FISH and RT-PCR methods, was demonstrated by Heyer et al. in a clinical cohort comprised of hematological and solid tumors (prostate, sarcoma, and lung cancers). Although RNAseq can overcome many limitations of the traditional techniques, it still suffers from poor sensitivity for detecting fusion genes that are lowly expressed or diluted by accompanying non-cancerous cells within a sample, due to the total size of the transcriptome [104]. Plenty of works demonstrate the utility of different trascriptome-based platforms (i.e., Nanostring Elements, Agena LungFusion panel, ThermoFisher NGS fusion panel, Archer NGS, Ion Torrent AmpliseqTM Colon, and lung cancer panel) commercially available for the identification of rearrangements in a large set of genes, all revealing a good concordance of results compared with FISH analysis $[19,103,108]$. Overall, an NGS approach can offer many advantages for diagnostic laboratory testing several cancers samples: (a) allows detection of multiple fusions in a single assay and can easily also be multiplexed with detection of point mutations and small insertions and deletions; (b) the single-assay format allows 
for faster turn-around-time and lower cost than doing the assays separately; (c) utilization of small amount of input RNA required is very valuable for these samples $[19,103,104,108]$.

In colorectal cancer, several fusion genes are generated by small intrachromosomal inversions, deletions or insertions making split-apart FISH signals very challenging, if not impossible, to visualize. For instance, as illustrated by Figure 1A, complex intrachromosomal fusion rearrangements involving $B R A F$ and some of its partner genes, in particular MKNR1 and TRIM24 present difficult interpretation of FISH analysis considering that the distance between them is quite small. A similar scenario is presented by gene fusions created with RET (Figure 1B) where NCOA4 and CCDC6 are also located close to each other, and RET and split-signals indicating presence of rearrangement could be easily missed. Considering these limitations, in addition to all the previously mentioned ones, 'actionable' fusion genes in colon cancer should be investigated utilizing high-throughput methods such as targeted NGS platforms, either specifically customized for colon cancer or utilizing other panels containing most of the targets of interest.

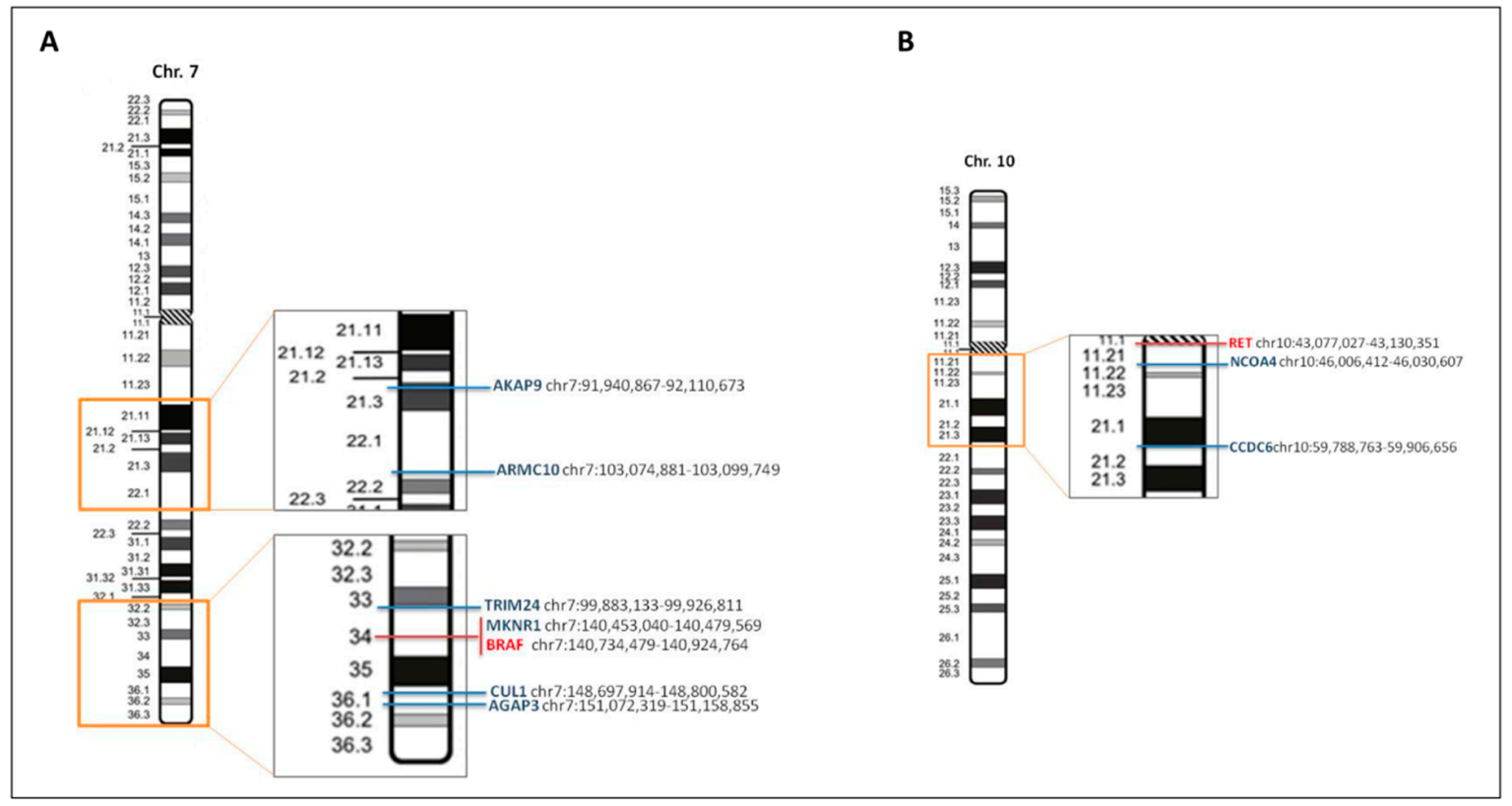

Figure 1. Genetic map of BRAF and RET and their partner genes. (A) Genetic and physical map of the chromosome 7, indicating (in the enlarged rectangles) the location of BRAF (in red) and some of its gene partners (in blue). (B) Moreover, for chromosome 10, containing RET (in red), some of the intrachromosomal genes partners are indicated in blue. Maps and gene location are derived from the website of the University of California Santa Cruz Genome Browser (http://genome.ucsc.edu/), with adaptations.

Lastly, as novel fusion genes or fusion partners are detected, and their clinical implication is confirmed, a periodical update of the primer pool would facilitate the continuing utility of this assay, inclusive of all potentially targetable gene fusions in cancer.

\section{Discussion}

We focused on oncogenes known to drive carcinogenesis, aggressiveness of tumor, and whose activating alterations such point mutations or gene amplifications are in some cases already targetable in mCRC. As described, fusions and mutations are mutually exclusive, both leading to an over-activation of the gene involved, and either of these aberrations may render the tumors sensitive to therapeutic targeting.

To date, the therapeutic algorithm for the choice of the best treatment for mCRC patients has been characterized by a negative selection, restricting the treatment with anti-EGFR agents to patients with 
wild-type RAS and BRAF mCRC [109,110]. Moving forward the era of positive selection in mCRC, results from the phase III BEACON trial, which randomized 665 pretreated patients with BRAF V600E mutant $\mathrm{mCRC}$ to receive triplet therapy (encorafenib, binimetinib and cetuximab), doublet therapy (encorafenib and cetuximab), or the investigator's choice of irinotecan or FOLFIRI and cetuximab, showed an impressive median overall survival of 9 months (95\% confidence interval (CI): $8,11.4)$ for the triplet targeted therapy compared to 5.4 months (95\% CI: $4.8,6.6)$ for standard therapy (hazard ratio (HR) $0.52 ; 95 \%$ CI: $0.39,0.7, p<0.0001)$ and an ORR of $26 \%(95 \%$ CI: 18,35$)$ for the triplet targeted therapy compared to $2 \%(95 \%$ CI: $0,7, p<0.0001)$ for standard therapy [111,112]. An analogous approach, with the inhibition of the entire axis of EGFR signal transduction, could be effective in mCRC patients harboring a $B R A F$ gene fusion.

Focusing on molecular biomarkers leading to a positive selection of $\mathrm{mCRC}$ patients, the phase II HERACLES study showed the activity of the combination of trastuzumab and lapatinib in HER2-amplified heavily pretreated mCRC patients [101], demonstrating that targeting HER2 is a successful therapeutic strategy in $\mathrm{mCRC}$, to be tested in HER2-rearranged mCRC patients.

However, gene fusions detected with deep sequencing may represent chance events caused by tumor's chromosomal instability, with poor pathogenic and druggable significant, underlining the need to classify gene fusions by functional assays. The poor cost-effectiveness of assessing such rare alterations in the daily clinical practice represents another limitation to the tailored treatment of mCRC patients harboring gene fusions. Nevertheless, selection criteria for screening of patients who may bear a gene fusion are already available thanks to retrospective efforts that identified clinical and pathological characteristics linked to the presence of such alterations. Furthermore, the importance of an early recognition of specific gene rearrangements is underlined by their negative prognostic role and potential negative predictive impact from anti-EGFR treatment, characteristics possibly driven by the high presence of microsatellite instability status in this patient population $[19,21,27,74]$.

Given these already available evidences, it seems reasonable to screen patients with a new diagnosis of RAS/BRAF wild-type mCRC for gene fusions by means of IHC testing and hopefully in the next future by targeted NGS panels. The importance of an early detection of potentially druggable fusions is underlined by the unfavorable prognostic role of such alterations. In fact, the reduced life expectancy of affected patients may significantly impair their chances to receive a targeted treatment and to be enrolled in dedicated clinical trials. Less evidences are available to determine the best first-line standard treatment for $\mathrm{mCRC}$ patients harboring a kinase gene fusion. Nevertheless, the aggressive clinical course of these tumors and the limited benefit achieved with anti-EGFR treatments in patients with ALK-ROS1-NTRK- or RET- rearranged mCRC [21,113] may suggest an intensified chemotherapy regimen such the triplet FOLFOXIRI plus bevacizumab as the best first-line treatment, while the enrollment in a fusion-targeted clinical trial should be considered as long as available.

As previously underlined, BRAF/RAS wild-type, MSI-H mCRC are enriched for targetable gene fusions [19,31]. In detail, only MSI-H mCRC in which MLH1 expression has been silenced by the gene promoter methylation are associated with an enrichment of kinase fusions, rather than MSI-H tumors caused by germline or somatic mutations in MMR genes [31]. Therefore, these data suggest that the prevalence of Lynch syndrome in MSI-H tumors harboring gene fusions may be extremely low, mirroring what has been demonstrated for BRAF V600E mutations. Immune-checkpoint inhibition either with pembrolizumab or nivolumab monotherapy and with nivolumab plus ipilimumab combination has been recently approved by FDA for the treatment of MSI-H mCRC patients, with response rates ranging from $31 \%$ to $60 \%$ [114-117]. No data are currently available on the differential outcomes between MSI-H mCRC patients with or without gene fusions, even if responses to treatment are usually independent from the presence of other driver alterations such as KRAS or BRAF mutations. However, the combination of targeted agents and immunotherapy could be a successful strategy [118] and deserves further investigations in MSI-H, rearranged mCRC patients, even if the extremely low prevalence of such molecular subgroups challenges the real-world feasibility of dedicated clinical trials. 
In conclusion, actionable gene fusions are rare in $\mathrm{mCRC}$ overall but reach a significant percentage in a selected population of patients that could benefit from an extremely active treatment either with a targeted agent or in combination with immune-checkpoint inhibitors.

Author Contributions: Conceptualization F.P. (Filippo Pagani), G.R., V.G., A.R., M.P., R.L., M.D.B., G.S., F.d.B., F.P. (Filippo Pietrantonio), P.G.; writing—original draft preparation, F.P. (Filippo Pagani), G.R., V.G., A.R., M.P., R.L., F.P. (Filippo Pietrantonio), P.G.; writing-review and editing, visualization, F.P. (Filippo Pagani), G.R., V.G., A.R., M.P., R.L., M.D.B., G.S., F.d.B., F.P. (Filippo Pietrantonio), P.G.; supervision, F.P. (Filippo Pietrantonio), P.G., G.S., M.D.B., F.d.B.

Funding: This research received no external funding.

Conflicts of Interest: F.P. has received honoraria for speaker activities and participation in advisory boards from Sanofi, Amgen, Bayer, Servier, Lilly, Merck-Serono, Roche. M.D.B. has received honoraria for speaker activities and participation in advisory boards from Amgen, Roche, Lilly, Servier, Incyte, Celgene. F.d.B. has received honoraria for speaker activities and participation in advisory boards from Amgen, Roche, Novartis. F.P. (Filippo Pagani), G.R., V.G., A.R., M.P., R.L., G.S., and P.G. declare no conflict of interest.

\section{References}

1. Bray, F.; Ferlay, J.; Soerjomataram, I.; Siegel, R.L.; Torre, L.A.; Jemal, A. Global cancer statistics 2018: GLOBOCAN estimates of incidence and mortality worldwide for 36 cancers in 185 countries. CA Cancer J. Clin. 2018, 68, 394-424. [CrossRef] [PubMed]

2. Stintzing, S.; Modest, D.P.; Rossius, L.; Lerch, M.M.; von Weikersthal, L.F.; Decker, T.; Kiani, A.; Vehling-Kaiser, U.; Al-Batran, S.E.; Heintges, T.; et al. FOLFIRI plus cetuximab versus FOLFIRI plus bevacizumab for metastatic colorectal cancer (FIRE-3): A post-hoc analysis of tumour dynamics in the final RAS wild-type subgroup of this randomised open-label phase 3 trial. Lancet Oncol. 2016, 17, 1426-1434. [CrossRef]

3. Loupakis, F.; Cremolini, C.; Masi, G.; Lonardi, S.; Zagonel, V.; Salvatore, L.; Cortesi, E.; Tomasello, G.; Ronzoni, M.; Spadi, R.; et al. Initial therapy with FOLFOXIRI and bevacizumab for metastatic colorectal cancer. N. Engl. J. Med. 2014, 371, 1609-1618. [CrossRef] [PubMed]

4. Simkens, L.H.; van Tinteren, H.; May, A.; ten Tije, A.J.; Creemers, G.J.; Loosveld, O.J.; de Jongh, F.E.; Erdkamp, F.L.; Erjavec, Z.; van der Torren, A.M.; et al. Maintenance treatment with capecitabine and bevacizumab in metastatic colorectal cancer (CAIRO3): A phase 3 randomised controlled trial of the Dutch Colorectal Cancer Group. Lancet 2015, 385, 1843-1852. [CrossRef]

5. Modest, D.P.; Pant, S.; Sartore-Bianchi, A. Treatment sequencing in metastatic colorectal cancer. Eur. J. Cancer 2019, 109, 70-83. [CrossRef] [PubMed]

6. Van Cutsem, E.; Cervantes, A.; Adam, R.; Sobrero, A.; Van Krieken, J.H.; Aderka, D.; Aranda Aguilar, E.; Bardelli, A.; Benson, A.; Bodoky, G.; et al. ESMO consensus guidelines for the management of patients with metastatic colorectal cancer. Ann. Oncol. 2016, 27, 1386-1422. [CrossRef]

7. National Comprehensive Cancer Network. Colon Cancer (version 1.2019). Available online: https: //www.nccn.org/professionals/physician_gls/pdf/colon.pdf (accessed on 15 June 2019).

8. Pietrantonio, F.; Petrelli, F.; Coinu, A.; Di Bartolomeo, M.; Borgonovo, K.; Maggi, C.; Cabiddu, M.; Iacovelli, R.; Bossi, I.; Lonati, V.; et al. Predictive role of BRAF mutations in patients with advanced colorectal cancer receiving cetuximab and panitumumab: A meta-analysis. Eur. J. Cancer 2015, 51, 587-594. [CrossRef]

9. Network, C.G.A. Comprehensive molecular characterization of human colon and rectal cancer. Nature 2012, 487, 330-337. [CrossRef]

10. Haan, J.C.; Labots, M.; Rausch, C.; Koopman, M.; Tol, J.; Mekenkamp, L.J.; van de Wiel, M.A.; Israeli, D.; van Essen, H.F.; van Grieken, N.C.; et al. Genomic landscape of metastatic colorectal cancer. Nat. Commun. 2014, 5, 5457. [CrossRef]

11. Yaeger, R.; Chatila, W.K.; Lipsyc, M.D.; Hechtman, J.F.; Cercek, A.; Sanchez-Vega, F.; Jayakumaran, G.; Middha, S.; Zehir, A.; Donoghue, M.T.A.; et al. Clinical sequencing defines the genomic landscape of metastatic colorectal cancer. Cancer Cell 2018, 33, 125-136. [CrossRef]

12. Valeri, N. Streamlining detection of fusion genes in colorectal cancer: Having "faith" in precision oncology in the (tissue) "agnostic" era. Cancer Res. 2019, 79, 1041-1043. [CrossRef] [PubMed] 
13. Mertens, F.; Johansson, B.; Fioretos, T.; Mitelman, F. The emerging complexity of gene fusions in cancer. Nat. Rev. Cancer 2015, 15, 371-381. [CrossRef] [PubMed]

14. Stransky, N.; Cerami, E.; Schalm, S.; Kim, J.L.; Lengauer, C. The landscape of kinase fusions in cancer. Nat. Commun. 2014, 5, 4846. [CrossRef] [PubMed]

15. Kumar-Sinha, C.; Kalyana-Sundaram, S.; Chinnaiyan, A.M. Landscape of gene fusions in epithelial cancers: Seq and ye shall find. Genome Med. 2015, 7, 129. [CrossRef]

16. Kloosterman, W.P.; van den Braak, R.R.J.C.; Pieterse, M.; van Roosmalen, M.J.; Sieuwerts, A.M.; Stangl, C.; Brunekreef, R.; Lalmahomed, Z.S.; Ooft, S.; van Galen, A.; et al. A systematic analysis of oncogenic gene fusions in primary colon cancer. Cancer Res. 2017, 77, 3814-3822. [CrossRef]

17. Roche. Media Release. Available online: https://www.roche.com/media/releases/med-cor-2019-02-19b.htm (accessed on 15 June 2019).

18. Drilon, A.; Laetsch, T.W.; Kummar, S.; DuBois, S.G.; Lassen, U.N.; Demetri, G.D.; Nathenson, M.; Doebele, R.C.; Farago, A.F.; Pappo, A.S.; et al. Efficacy of Larotrectinib in TRK fusion-positive cancers in adults and children. N. Engl. J. Med. 2018, 378, 731-739. [CrossRef]

19. Cocco, E.; Benhamida, J.; Middha, S.; Zehir, A.; Mullaney, K.; Shia, J.; Yaeger, R.; Zhang, L.; Wong, D.; Villafania, L.; et al. Colorectal carcinomas containing hypermethylated MLH1 promoter and wild-type BRAF/KRAS are enriched for targetable kinase fusions. Cancer Res. 2019, 79, 1047-1053. [CrossRef]

20. Medico, E.; Russo, M.; Picco, G.; Cancelliere, C.; Valtorta, E.; Corti, G.; Buscarino, M.; Isella, C.; Lamba, S.; Martinoglio, B.; et al. The molecular landscape of colorectal cancer cell lines unveils clinically actionable kinase targets. Nat. Commun. 2015, 6, 7002. [CrossRef]

21. Cremolini, C.; Morano, F.; Moretto, R.; Berenato, R.; Tamborini, E.; Perrone, F.; Rossini, D.; Gloghini, A.; Busico, A.; Zucchelli, G.; et al. Negative hyper-selection of metastatic colorectal cancer patients for anti-EGFR monoclonal antibodies: The PRESSING case-control study. Ann. Oncol. 2017, 28, 3009-3014. [CrossRef]

22. Cocco, E.; Scaltriti, M.; Drilon, A. NTRK fusion-positive cancers and TRK inhibitor therapy. Nat. Rev. Clin. Oncol. 2018, 15, 731-747. [CrossRef]

23. Okamura, R.; Boichard, A.; Kato, S.; Sicklick, J.K.; Bazhenova, L.; Kurzrock, R. Analysis of NTRK alterations in pan-cancer adult and pediatric malignancies: Implications for NTRK-targeted therapeutics. JCO Precis. Oncol. 2018, 2018. [CrossRef] [PubMed]

24. Gatalica, Z.; Xiu, J.; Swensen, J.; Vranic, S. Molecular characterization of cancers with NTRK gene fusions. Mod Pathol. 2019, 32, 147-153. [CrossRef] [PubMed]

25. Milione, M.; Ardini, E.; Christiansen, J.; Valtorta, E.; Veronese, S.; Bosotti, R.; Pellegrinelli, A.; Testi, A.; Pietrantonio, F.; Fucà, G.; et al. Identification and characterization of a novel SCYL3-NTRK1 rearrangement in a colorectal cancer patient. Oncotarget 2017, 8, 55353-55360. [CrossRef] [PubMed]

26. Hechtman, J.F.; Benayed, R.; Hyman, D.M.; Drilon, A.; Zehir, A.; Frosina, D.; Arcila, M.E.; Dogan, S.; Klimstra, D.S.; Ladanyi, M.; et al. Pan-trk immunohistochemistry is an efficient and reliable screen for the detection of NTRK fusions. Am. J. Surg. Pathol. 2017, 41, 1547-1551. [CrossRef] [PubMed]

27. Pietrantonio, F.; Di Nicolantonio, F.; Schrock, A.B.; Lee, J.; Tejpar, S.; Sartore-Bianchi, A.; Hechtman, J.F.; Christiansen, J.; Novara, L.; Tebbutt, N.; et al. ALK, ROS1, and NTRK rearrangements in metastatic colorectal cancer. J. Natl. Cancer Inst. 2017, 109. [CrossRef] [PubMed]

28. Amatu, A.; Sartore-Bianchi, A.; Siena, S. Gene fusions as novel targets of cancer therapy across multiple tumour types. ESMO Open 2016, 1, e000023. [CrossRef]

29. Hsiao, S.J.; Zehir, A.; Sireci, A.N.; Aisner, D.L. Detection of tumor NTRK gene fusions to identify patients who may benefit from tyrosine kinase (TRK) inhibitor therapy. J. Mol. Diagn. 2019, 21, 553-571. [CrossRef]

30. Hechtman, J.F.; Zehir, A.; Yaeger, R.; Wang, L.; Middha, S.; Zheng, T.; Hyman, D.M.; Solit, D.; Arcila, M.E.; Borsu, L.; et al. Identification of Targetable kinase alterations in patients with colorectal carcinoma that are preferentially associated with wild-type RAS/RAF. Mol. Cancer Res. 2016, 14, 296-301. [CrossRef]

31. Sato, K.; Kawazu, M.; Yamamoto, Y.; Ueno, T.; Kojima, S.; Nagae, G.; Abe, H.; Soda, M.; Oga, T.; Kohsaka, S.; et al. Fusion kinases identified by genomic analyses of sporadic microsatellite instability-high colorectal cancers. Clin. Cancer Res. 2019, 25, 378-389. [CrossRef]

32. Lipson, D.; Capelletti, M.; Yelensky, R.; Otto, G.; Parker, A.; Jarosz, M.; Curran, J.A.; Balasubramanian, S.; Bloom, T.; Brennan, K.W.; et al. Identification of new ALK and RET gene fusions from colorectal and lung cancer biopsies. Nat. Med. 2012, 18, 382-384. [CrossRef] 
33. Yakirevich, E.; Resnick, M.B.; Mangray, S.; Wheeler, M.; Jackson, C.L.; Lombardo, K.A.; Lee, J.; Kim, K.M.; Gill, A.J.; Wang, K.; et al. Oncogenic ALK fusion in rare and aggressive subtype of colorectal adenocarcinoma as a potential therapeutic target. Clin. Cancer Res. 2016, 22, 3831-3840. [CrossRef]

34. Lee, J.; Kim, H.C.; Hong, J.Y.; Wang, K.; Kim, S.Y.; Jang, J.; Kim, S.T.; Park, J.O.; Lim, H.Y.; Kang, W.K.; et al. Detection of novel and potentially actionable anaplastic lymphoma kinase (ALK) rearrangement in colorectal adenocarcinoma by immunohistochemistry screening. Oncotarget 2015, 6, 24320-24332. [CrossRef]

35. Selvam, P.; Kelly, K.; Hesse, A.N.; Spitzer, D.; Reddi, H.V. Evaluating gene fusions in solid tumors-Clinical experience using an RNA based 53 gene next-generation sequencing panel. Cancer Genet. 2019, 233-234, 32-42. [CrossRef]

36. Choi, Y.; Kwon, C.H.; Lee, S.J.; Park, J.; Shin, J.Y.; Park, D.Y. Integrative analysis of oncogenic fusion genes and their functional impact in colorectal cancer. Br. J. Cancer 2018, 119, 230-240. [CrossRef]

37. Jang, J.E.; Kim, H.P.; Han, S.W.; Jang, H.; Lee, S.H.; Song, S.H.; Bang, D.; Kim, T.Y. NFATC3-PLA2G15 fusion transcript identified by RNA sequencing promotes tumor invasion and proliferation in colorectal cancer cell lines. Cancer Res. Treat. 2019, 51, 391-401. [CrossRef]

38. Ardini, E.; Menichincheri, M.; Banfi, P.; Bosotti, R.; De Ponti, C.; Pulci, R.; Ballinari, D.; Ciomei, M.; Texido, G.; Degrassi, A.; et al. Entrectinib, a Pan-TRK, ROS1, and ALK inhibitor with activity in multiple molecularly defined cancer indications. Mol. Cancer 2016, 15, 628-639. [CrossRef]

39. Drilon, A.; Siena, S.; Ou, S.I.; Patel, M.; Ahn, M.J.; Lee, J.; Bauer, T.M.; Farago, A.F.; Wheler, J.J.; Liu, S.V.; et al. Safety and antitumor activity of the multitargeted pan-TRK, ROS1, and ALK inhibitor entrectinib: Combined results from two phase I trials (ALKA-372-001 and STARTRK-1). Cancer Discov. 2017, 7, 400-409. [CrossRef]

40. Basket Study of Entrectinib (RXDX-101) for the Treatment of Patients WITH Solid Tumors Harboring NTRK 1/2/3 (Trk A/B/C), ROS1, or ALK Gene Rearrangements (Fusions) (STARTRK-2). Available online: https://clinicaltrials.gov/ct2/show/NCT02568267 (accessed on 15 June 2019).

41. Study of Entrectinib (Rxdx-101) in Children and Adolescents with no Curative First-Line Treatment Option, Recurrent or Refractory Solid Tumors and Primary Cns Tumors, with or without Trk, Ros1, or Alk Fusions. Available online: https://clinicaltrials.gov/ct2/show/NCT02650401 (accessed on 15 June 2019).

42. Solomon, B.J.; Mok, T.; Kim, D.W.; Wu, Y.L.; Nakagawa, K.; Mekhail, T.; Felip, E.; Cappuzzo, F.; Paolini, J.; Usari, T.; et al. First-line crizotinib versus chemotherapy in ALK-positive lung cancer. N. Engl. J. Med. 2014, 371, 2167-2177. [CrossRef]

43. Peters, S.; Camidge, D.R.; Shaw, A.T.; Gadgeel, S.; Ahn, J.S.; Kim, D.W.; Ou, S.I.; Pérol, M.; Dziadziuszko, R.; Rosell, R.; et al. Alectinib versus crizotinib in untreated ALK-positive non-small-cell lung cancer. N. Engl. J. Med. 2017, 377, 829-838. [CrossRef]

44. Camidge, D.R.; Kim, H.R.; Ahn, M.J.; Yang, J.C.; Han, J.Y.; Lee, J.S.; Hochmair, M.J.; Li, J.Y.; Chang, G.C.; Lee, K.H.; et al. Brigatinib versus crizotinib in ALK-positive non-small-cell lung Cancer. N. Engl. J. Med. 2018, 379, 2027-2039. [CrossRef]

45. Soria, J.C.; Tan, D.S.W.; Chiari, R.; Wu, Y.L.; Paz-Ares, L.; Wolf, J.; Geater, S.L.; Orlov, S.; Cortinovis, D.; Yu, C.J.; et al. First-line ceritinib versus platinum-based chemotherapy in advanced ALK-rearranged non-small-cell lung cancer (ASCEND-4): A randomised, open-label, phase 3 study. Lancet 2017, 389, 917-929. [CrossRef]

46. Solomon, B.J.; Besse, B.; Bauer, T.M.; Felip, E.; Soo, R.A.; Camidge, D.R.; Chiari, R.; Bearz, A.; Lin, C.C.; Gadgeel, S.M.; et al. Lorlatinib in patients with ALK-positive non-small-cell lung cancer: Results from a global phase 2 study. Lancet Oncol. 2018, 19, 1654-1667. [CrossRef]

47. Shaw, A.T.; Ou, S.H.; Bang, Y.J.; Camidge, D.R.; Solomon, B.J.; Salgia, R.; Riely, G.J.; Varella-Garcia, M.; Shapiro, G.I.; Costa, D.B.; et al. Crizotinib in ROS1-rearranged non-small-cell lung cancer. N. Engl. J. Med. 2014, 371, 1963-1971. [CrossRef]

48. Wells, S.A., Jr.; Robinson, B.G.; Gagel, R.F.; Dralle, H.; Fagin, J.A.; Santoro, M.; Baudin, E.; Elisei, R.; Jarzab, B.; Vasselli, J.R.; et al. Vandetanib in patients with locally advanced or metastatic medullary thyroid cancer: A randomized, double-blind phase III trial. J. Clin. Oncol. 2012, 30, 134-141. [CrossRef]

49. Schlumberger, M.; Tahara, M.; Wirth, L.J.; Robinson, B.; Brose, M.S.; Elisei, R.; Habra, M.A.; Newbold, K.; Shah, M.H.; Hoff, A.O.; et al. Lenvatinib versus placebo in radioiodine-refractory thyroid cancer. N. Engl. J. Med. 2015, 372, 621-630. [CrossRef] 
50. Motzer, R.J.; Hutson, T.E.; Glen, H.; Michaelson, M.D.; Molina, A.; Eisen, T.; Jassem, J.; Zolnierek, J.; Maroto, J.P.; Mellado, B.; et al. Lenvatinib, everolimus, and the combination in patients with metastatic renal cell carcinoma: A randomised, phase 2, open-label, multicentre trial. Lancet Oncol. 2015, 16, 1473-1482. [CrossRef]

51. Escudier, B.; Eisen, T.; Stadler, W.M.; Szczylik, C.; Oudard, S.; Siebels, M.; Negrier, S.; Chevreau, C.; Solska, E.; Desai, A.A.; et al. Sorafenib in advanced clear-cell renal-cell carcinoma. N. Engl. J. Med. 2007, 356, 125-134. [CrossRef]

52. Llovet, J.M.; Ricci, S.; Mazzaferro, V.; Hilgard, P.; Gane, E.; Blanc, J.F.; de Oliveira, A.C.; Santoro, A.; Raoul, J.L.; Forner, A.; et al. Sorafenib in advanced hepatocellular carcinoma. N. Engl. J. Med. 2008, 359, 378-390. [CrossRef]

53. Grothey, A.; Van Cutsem, E.; Sobrero, A.; Siena, S.; Falcone, A.; Ychou, M.; Humblet, Y.; Bouche, O.; Mineur, L.; Barone, C.; et al. Regorafenib monotherapy for previously treated metastatic colorectal cancer (CORRECT): An international, multicentre, randomised, placebo-controlled, phase 3 trial. Lancet 2013, 381, 303-312. [CrossRef]

54. Gainor, J.F.; Lee, D.H.; Curigliano, G.; Doebele, R.C.; Kim, D.-W.; Baik, C.S.; Tan, D.S.-W.; Lopes, G.; Gadgeel, S.M.; Cassier, P.A.; et al. Clinical activity and tolerability of BLU-667, a highly potent and selective RET inhibitor, in patients (pts) with advanced RET-fusion+ non-small cell lung cancer (NSCLC). J. Clin. Oncol. 2019, 37 (Suppl. 15), 9008.

55. Taylor, M.H.; Gainor, J.F.; Hu, M.I.-N.; Zhu, V.W.; Lopes, G.; Leboulleux, S.; Brose, M.S.; Schuler, M.H.; Bowles, D.W.; Kim, D.-W.; et al. Activity and tolerability of BLU-667, a highly potent and selective RET inhibitor, in patients with advanced RET-altered thyroid cancers. J. Clin. Oncol. 2019, 37 (Suppl. 15), 6018. [CrossRef]

56. Drilon, A.E.; Subbiah, V.; Oxnard, G.R.; Bauer, T.M.; Velcheti, V.; Lakhani, N.J.; Besse, B.; Park, K.; Patel, J.D.; Cabanillas, M.E.; et al. A phase 1 study of LOXO-292, a potent and highly selective RET inhibitor, in patients with RET-altered cancers. J. Clin. Oncol. 2018, 36 (Suppl. 15), 102. [CrossRef]

57. Loriot, Y.; Necchi, A.; Park, S.H.; Garcia-Donas, J.; Huddart, R.; Burgess, E.; Fleming, M.; Rezazadeh, A.; Mellado, B.; Varlamov, S.; et al. Erdafitinib in locally advanced or metastatic urothelial carcinoma. N. Engl. J. Med. 2019, 381, 338-348. [CrossRef]

58. Hallberg, B.; Palmer, R.H. The role of the ALK receptor in cancer biology. Ann. Oncol 2016, 27 (Suppl. 3), iii4-iii15. [CrossRef]

59. Bergethon, K.; Shaw, A.T.; Ou, S.H.; Katayama, R.; Lovly, C.M.; McDonald, N.T.; Massion, P.P.; Siwak-Tapp, C.; Gonzalez, A.; Fang, R.; et al. ROS1 rearrangements define a unique molecular class of lung cancers. J. Clin. Oncol. 2012, 30, 863-870. [CrossRef]

60. Sasaki, T.; Rodig, S.J.; Chirieac, L.R.; Jänne, P.A. The biology and treatment of EML4-ALK non-small cell lung cancer. Eur. J. Cancer 2010, 46, 1773-1780. [CrossRef]

61. Alese, O.B.; El-Rayes, B.F.; Sica, G.; Zhang, G.; Alexis, D.; La Rosa, F.G.; Varella-Garcia, M.; Chen, Z.; Rossi, M.R.; Adsay, N.V.; et al. Anaplastic lymphoma kinase (ALK) gene alteration in signet ring cell carcinoma of the gastrointestinal tract. Adv. Med. Oncol. 2015, 7, 56-62. [CrossRef]

62. Lin, E.; Li, L.; Guan, Y.; Soriano, R.; Rivers, C.S.; Mohan, S.; Pandita, A.; Tang, J.; Modrusan, Z. Exon array profiling detects EML4-ALK fusion in breast, colorectal, and non-small cell lung cancers. Mol. Cancer Res. 2009, 7, 1466-1476. [CrossRef]

63. Bavi, P.; Jehan, Z.; Bu, R.; Prabhakaran, S.; Al-Sanea, N.; Al-Dayel, F.; Al-Assiri, M.; Al-Halouly, T.; Sairafi, R.; Uddin, S.; et al. ALK gene amplification is associated with poor prognosis in colorectal carcinoma. Br. J. Cancer 2013, 109, 2735-2743. [CrossRef]

64. Amatu, A.; Somaschini, A.; Cerea, G.; Bosotti, R.; Valtorta, E.; Buonandi, P.; Marrapese, G.; Veronese, S.; Luo, D.; Hornby, Z.; et al. Novel CAD-ALK gene rearrangement is drugable by entrectinib in colorectal cancer. Br. J. Cancer 2015, 113, 1730-1734. [CrossRef]

65. Houang, M.; Toon, C.W.; Clarkson, A.; Sioson, L.; de Silva, K.; Watson, N.; Singh, N.R.; Chou, A.; Gill, A.J. ALK and ROS1 overexpression is very rare in colorectal adenocarcinoma. Appl. Immunohistochem. Mol. Morphol. 2015, 23, 134-138. [CrossRef] [PubMed]

66. Ying, J.; Lin, C.; Wu, J.; Guo, L.; Qiu, T.; Ling, Y.; Shan, L.; Zhou, H.; Zhao, D.; Wang, J.; et al. Anaplastic lymphoma kinase rearrangement in digestive tract cancer: Implication for targeted therapy in Chinese population. PLoS ONE 2015, 10, e0144731. [CrossRef] [PubMed] 
67. Aisner, D.L.; Nguyen, T.T.; Paskulin, D.D.; Le, A.T.; Haney, J.; Schulte, N.; Chionh, F.; Hardingham, J.; Mariadason, J.; Tebbutt, N.; et al. ROS1 and ALK fusions in colorectal cancer, with evidence of intratumoral heterogeneity for molecular drivers. Mol. Cancer Res. 2014, 12, 111-118. [CrossRef] [PubMed]

68. Mulligan, L.M. RET revisited: Expanding the oncogenic portfolio. Nat. Rev. Cancer 2014, 14, 173. [CrossRef] [PubMed]

69. Drilon, A.; Hu, Z.I.; Lai, G.G.Y.; Tan, D.S.W. Targeting RET-driven cancers: Lessons from evolving preclinical and clinical landscapes. Nat. Rev. Clin. Oncol. 2017, 15, 151. [CrossRef] [PubMed]

70. Romei, C.; Elisei, R. RET/PTC Translocations and clinico-pathological features in human papillary thyroid carcinoma. Front. Endocrinol. 2012, 3, 54. [CrossRef]

71. Kohno, T.; Ichikawa, H.; Totoki, Y.; Yasuda, K.; Hiramoto, M.; Nammo, T.; Sakamoto, H.; Tsuta, K.; Furuta, K.; Shimada, Y.; et al. KIF5B-RET fusions in lung adenocarcinoma. Nat. Med. 2012, 18, 375-377. [CrossRef]

72. Takeuchi, K.; Soda, M.; Togashi, Y.; Suzuki, R.; Sakata, S.; Hatano, S.; Asaka, R.; Hamanaka, W.; Ninomiya, H.; Uehara, H.; et al. RET, ROS1 and ALK fusions in lung cancer. Nat. Med. 2012, 18, 378. [CrossRef]

73. Le Rolle, A.-F.; Klempner, S.J.; Garrett, C.R.; Seery, T.; Sanford, E.M.; Balasubramanian, S.; Ross, J.S.; Stephens, P.J.; Miller, V.A.; Ali, S.M.; et al. Identification and characterization of RET fusions in advanced colorectal cancer. Oncotarget 2015, 6, 28929-28937. [CrossRef]

74. Pietrantonio, F.; Di Nicolantonio, F.; Schrock, A.B.; Lee, J.; Morano, F.; Fucà, G.; Nikolinakos, P.; Drilon, A.; Hechtman, J.F.; Christiansen, J.; et al. RET fusions in a small subset of advanced colorectal cancers at risk of being neglected. Ann. Oncol. 2018, 29, 1394-1401. [CrossRef]

75. Roskoski, R.; Sadeghi-Nejad, A. Role of RET protein-tyrosine kinase inhibitors in the treatment RET-driven thyroid and lung cancers. Pharmacol. Res. 2018, 128, 1-17. [CrossRef] [PubMed]

76. Schlumberger, M.; Elisei, R.; Müller, S.; Schöffski, P.; Brose, M.; Shah, M.; Licitra, L.; Krajewska, J.; Kreissl, M.C.; Niederle, B.; et al. Overall survival analysis of EXAM, a phase III trial of cabozantinib in patients with radiographically progressive medullary thyroid carcinoma. Ann. Oncol. 2017, 28, 2813-2819. [CrossRef] [PubMed]

77. Brose, M.S.; Nutting, C.M.; Jarzab, B.; Elisei, R.; Siena, S.; Bastholt, L.; de la Fouchardiere, C.; Pacini, F.; Paschke, R.; Shong, Y.K.; et al. Sorafenib in radioactive iodine-refractory, locally advanced or metastatic differentiated thyroid cancer: A randomised, double-blind, phase 3 trial. Lancet 2014, 384, 319-328. [CrossRef]

78. Subbiah, V.; Gainor, J.F.; Rahal, R.; Brubaker, J.D.; Kim, J.L.; Maynard, M.; Hu, W.; Cao, Q.; Sheets, M.P.; Wilson, D.; et al. Precision targeted therapy with BLU-667 for RET-driven cancers. Cancer Discov. 2018, 8, 836-849. [CrossRef] [PubMed]

79. Subbiah, V.; Velcheti, V.; Tuch, B.B.; Ebata, K.; Busaidy, N.L.; Cabanillas, M.E.; Wirth, L.J.; Stock, S.; Smith, S.; Lauriault, V.; et al. Selective RET kinase inhibition for patients with RET-altered cancers. Ann. Oncol. 2018, 29, 1869-1876. [CrossRef]

80. Phase 1/2 Study of the Highly-selective RET Inhibitor, Pralsetinib (BLU-667), in Patients with Thyroid Cancer, Non-Small Cell Lung Cancer, and Other Advanced Solid Tumors (ARROW). Available online: https://clinicaltrials.gov/ct2/show/NCT03037385 (accessed on 16 June 2019).

81. Phase 1/2 Study of LOXO-292 in Patients with Advanced Solid Tumors, RET Fusion-Positive Solid Tumors, and Medullary Thyroid Cancer (LIBRETTO-001). Available online: https://linicaltrials.gov/ct2/show/ NCT03157128 (accessed on 16 June 2019).

82. Peeters, M.; Oliner, K.S.; Parker, A.; Siena, S.; Van Cutsem, E.; Huang, J.; Humblet, Y.; Van Laethem, J.L.; André, T.; Wiezorek, J.; et al. Massively parallel tumor multigene sequencing to evaluate response to panitumumab in a randomized phase III study of metastatic colorectal cancer. Clin. Cancer Res. 2013, 19, 1902-1912. [CrossRef]

83. Loupakis, F.; Moretto, R.; Aprile, G.; Muntoni, M.; Cremolini, C.; Iacono, D.; Casagrande, M.; Ferrari, L.; Salvatore, L.; Schirripa, M.; et al. Clinico-pathological nomogram for predicting BRAF mutational status of metastatic colorectal cancer. Br. J. Cancer 2016, 114, 30-36. [CrossRef]

84. Jones, D.T.; Kocialkowski, S.; Liu, L.; Pearson, D.M.; Bäcklund, L.M.; Ichimura, K.; Collins, V.P. Tandem duplication producing a novel oncogenic BRAF fusion gene defines the majority of pilocytic astrocytomas. Cancer Res. 2008, 68, 8673-8677. [CrossRef]

85. Cordioli, M.I.; Moraes, L.; Carvalheira, G.; Sisdelli, L.; Alves, M.T.; Delcelo, R.; Monte, O.; Longui, C.A.; Cury, A.N.; Cerutti, J.M. AGK-BRAF gene fusion is a recurrent event in sporadic pediatric thyroid carcinoma. Cancer Med. 2016, 5, 1535-1541. [CrossRef] 
86. Kulkarni, A.; Al-Hraishawi, H.; Simhadri, S.; Hirshfield, K.M.; Chen, S.; Pine, S.; Jeyamohan, C.; Sokol, L.; Ali, S.; Teo, M.L.; et al. BRAF fusion as a novel mechanism of acquired resistance to vemurafenib in BRAF V600E mutant melanoma. Clin. Cancer Res. 2017, 23, 5631-5638. [CrossRef]

87. Hutchinson, K.E.; Lipson, D.; Stephens, P.J.; Otto, G.; Lehmann, B.D.; Lyle, P.L.; Vnencak-Jones, C.L.; Ross, J.S.; Pietenpol, J.A.; Sosman, J.A.; et al. BRAF fusions define a distinct molecular subset of melanomas with potential sensitivity to MEK inhibition. Clin. Cancer Res. 2013, 19, 6696-6702. [CrossRef] [PubMed]

88. Ross, J.S.; Wang, K.; Chmielecki, J.; Gay, L.; Johnson, A.; Chudnovsky, J.; Yelensky, R.; Lipson, D.; Ali, S.M.; Elvin, J.A.; et al. The distribution of BRAF gene fusions in solid tumors and response to targeted therapy. Int. J. Cancer 2016, 138, 881-890. [CrossRef] [PubMed]

89. Knowles, M.A.; Hurst, C.D. Molecular biology of bladder cancer: New insights into pathogenesis and clinical diversity. Nat. Rev. Cancer 2015, 15, 25-41. [CrossRef] [PubMed]

90. Seshagiri, S.; Stawiski, E.W.; Durinck, S.; Modrusan, Z.; Storm, E.E.; Conboy, C.B.; Chaudhuri, S.; Guan, Y.; Janakiraman, V.; Jaiswal, B.S.; et al. Recurrent R-spondin fusions in colon cancer. Nature 2012, 488, 660-664. [CrossRef] [PubMed]

91. A Study of LGK974 in Patients with Malignancies Dependent on Wnt Ligands. Available online: https: //clinicaltrials.gov/ct2/show/NCT01351103 (accessed on 6 August 2019).

92. Hynes, N.E.; Lane, H.A. ERBB receptors and cancer: The complexity of targeted inhibitors. Nat. Rev. Cancer 2005, 5, 341-354. [CrossRef]

93. Ross, J.S.; Wang, K.; Sheehan, C.E.; Boguniewicz, A.B.; Otto, G.; Downing, S.R.; Sun, J.; He, J.; Curran, J.A.; Ali, S.; et al. Relapsed classic E-cadherin (CDH1) mutated invasive lobular breast cancer demonstrates a high frequency of HER2 (ERBB2) gene mutations. Clin. Cancer Res. 2013, 19, 2668. [CrossRef]

94. Ross, J.S.; Wang, K.; Gay, L.M.; Al-Rohil, R.N.; Nazeer, T.; Sheehan, C.E.; Jennings, T.A.; Otto, G.A.; Donahue, A.; He, J.; et al. A high frequency of activating extracellular domain ERBB2 (HER2) mutation in micropapillary urothelial carcinoma. Clin. Cancer Res. 2014, 20, 68. [CrossRef]

95. Chmielecki, J.; Ross, J.S.; Wang, K.; Frampton, G.M.; Palmer, G.A.; Ali, S.M.; Palma, N.; Morosini, D.; Miller, V.A.; Yelensky, R.; et al. Oncogenic alterations in ERBB2/HER2 represent potential therapeutic targets across tumors from diverse anatomic sites of origin. Oncologist 2015, 20,7-12. [CrossRef]

96. Connell, C.M.; Doherty, G.J. Activating HER2 mutations as emerging targets in multiple solid cancers. ESMO Open 2017, 2, e000279. [CrossRef]

97. Laurent-Puig, P.; Balogoun, R.; Cayre, A.; Le Malicot, K.; Tabernero, J.; Mini, E.; Folprecht, G.; van Laethem, J.L.; Thaler, J.; Petersen, L.N.; et al. Taieb ERBB2 alterations a new prognostic biomarker in stage III colon cancer from a FOLFOX based adjuvant trial (PETACC8). Ann. Oncol. 2016, 27, 149-206. [CrossRef]

98. Valtorta, E.; Martino, C.; Sartore-Bianchi, A.; Penaullt-Llorca, F.; Viale, G.; Risio, M.; Rugge, M.; Grigioni, W.; Bencardino, K.; Lonardi, S.; et al. Assessment of a HER2 scoring system for colorectal cancer: Results from a validation study. Mod Pathol. 2015, 28, 1481. [CrossRef] [PubMed]

99. Richman, S.D.; Southward, K.; Chambers, P.; Cross, D.; Barrett, J.; Hemmings, G.; Taylor, M.; Wood, H.; Hutchins, G.; Foster, J.M.; et al. HER2 overexpression and amplification as a potential therapeutic target in colorectal cancer: Analysis of 3256 patients enrolled in the QUASAR, FOCUS and PICCOLO colorectal cancer trials. J. Pathol. 2016, 238, 562-570. [CrossRef] [PubMed]

100. Siena, S.; Sartore-Bianchi, A.; Marsoni, S.; Hurwitz, H.I.; McCall, S.J.; Penault-Llorca, F.; Srock, S.; Bardelli, A.; Trusolino, L. Targeting the human epidermal growth factor receptor 2 (HER2) oncogene in colorectal cancer. Ann. Oncol 2018, 29, 1108-1119. [CrossRef] [PubMed]

101. Sartore-Bianchi, A.; Trusolino, L.; Martino, C.; Bencardino, K.; Lonardi, S.; Bergamo, F.; Zagonel, V.; Leone, F.; Depetris, I.; Martinelli, E.; et al. Dual-targeted therapy with trastuzumab and lapatinib in treatment-refractory, KRAS codon 12/13 wild-type, HER2-positive metastatic colorectal cancer (HERACLES): A proof-of-concept, multicentre, open-label, phase 2 trial. Lancet Oncol. 2016, 17, 738-746. [CrossRef]

102. Hainsworth, J.D.; Meric-Bernstam, F.; Swanton, C.; Hurwitz, H.; Spigel, D.R.; Sweeney, C.; Burris, H.A.; Bose, R.; Yoo, B.; Stein, A.; et al. Targeted therapy for advanced solid tumors on the basis of molecular profiles: Results from MyPathway, an open-label, phase IIa multiple basket study. J. Clin. Oncol. 2018, 36, 536-542. [CrossRef] 
103. Vaughn, C.P.; Costa, J.L.; Feilotter, H.E.; Petraroli, R.; Bagai, V.; Rachiglio, A.M.; Marino, F.Z.; Tops, B.; Kurth, H.M.; Sakai, K.; et al. Simultaneous detection of lung fusions using a multiplex RT-PCR next generation sequencing-based approach: A multi-institutional research study. BMC Cancer 2018, 18, 828. [CrossRef]

104. Heyer, E.E.; Deveson, I.W.; Wooi, D.; Selinger, C.I.; Lyons, R.J.; Hayes, V.M.; O’Toole, S.A.; Ballinger, M.L.; Gill, D.; Thomas, D.M.; et al. Diagnosis of fusion genes using targeted RNA sequencing. Nat. Commun. 2019, 10, 1388. [CrossRef]

105. Pfarr, N.; Stenzinger, A.; Penzel, R.; Warth, A.; Dienemann, H.; Schirmacher, P.; Weichert, W.; Endris, V. High-throughput diagnostic profiling of clinically actionable gene fusions in lung cancer. Genes Chromosom. Cancer 2016, 55, 30-44. [CrossRef]

106. Wallander, M.L.; Geiersbach, K.B.; Tripp, S.R.; Layfield, L.J. Comparison of reverse transcription-polymerase chain reaction, immunohistochemistry, and fluorescence in situ hybridization methodologies for detection of echinoderm microtubule-associated proteinlike 4-anaplastic lymphoma kinase fusion-positive non-small cell lung carcinoma: Implications for optimal clinical testing. Arch. Pathol. Lab. Med. 2012, 136, 796-803. [CrossRef]

107. Carter, T.C.; He, M.M. Challenges of identifying clinically actionable genetic variants for precision medicine. J. Healthc. Eng. 2016. [CrossRef]

108. Rogers, T.M.; Arnau, G.M.; Ryland, G.L.; Huang, S.; Lira, M.E.; Emmanuel, Y.; Perez, O.D.; Irwin, D.; Fellowes, A.P.; Wong, S.Q.; et al. Multiplexed transcriptome analysis to detect ALK, ROS1 and RET rearrangements in lung cancer. Sci. Rep. 2017, 7, 42259. [CrossRef] [PubMed]

109. Cremolini, C.; Schirripa, M.; Antoniotti, C.; Moretto, R.; Salvatore, L.; Masi, G.; Falcone, A.; Loupakis, F. First-line chemotherapy for $\mathrm{mCRC}-\mathrm{A}$ review and evidence-based algorithm. Nat. Rev. Clin. Oncol. 2015, 12, 607-619. [CrossRef] [PubMed]

110. Pietrantonio, F.; Morano, F.; Corallo, S.; Miceli, R.; Lonardi, S.; Raimondi, A.; Cremolini, C.; Rimassa, L.; Bergamo, F.; Sartore-Bianchi, A.; et al. Maintenance therapy with panitumumab alone vs panitumumab plus fluorouracil-leucovorin in patients with RAS wild-type metastatic colorectal cancer: A phase 2 randomized clinical trial. JAMA Oncol. 2019. [CrossRef] [PubMed]

111. Van Cutsem, E.; Huijberts, S.; Grothey, A.; Yaeger, R.; Cuyle, P.J.; Elez, E.; Fakih, M.; Montagut, C.; Peeters, M.; Yoshino, T.; et al. Binimetinib, encorafenib, and cetuximab triplet therapy for patients with BRAF V600E-mutant metastatic colorectal cancer: Safety lead-in results from the phase III BEACON colorectal cancer study. J. Clin. Oncol. 2019, 37, 1460-1469. [CrossRef] [PubMed]

112. Kopets, S.; Grothey, A.; Van Cutsem, A.; Yaeger, R.; Wasa, H.; Yoshino, T.; Desai, J.; Ciardiello, F.; Gollerkeri, A.; Maharry, K.; et al. BEACON CRC: A randomized, 3-Arm, phase 3 study of encorafenib and cetuximab with or without binimetinib vs. choice of either irinotecan or FOLFIRI plus cetuximab in BRAF V600E-mutant metastatic colorectal cancer. Ann. Oncol. 2019, 30. [CrossRef]

113. Morano, F.; Corallo, S.; Lonardi, S.; Raimondi, A.; Cremolini, C.; Rimassa, L.; Murialdo, R.; Zaniboni, A.; Sartore-Bianchi, A.; Tomasello, G.; et al. Negative hyperselection of patients with RAS and BRAF-wild-type metastatic colorectal cancer who received panitumumab-based maintenance therapy. J. Clin. Oncol. 2019, in press. [CrossRef]

114. Le, D.T.; Uram, J.N.; Wang, H.; Bartlett, B.R.; Kemberling, H.; Eyring, A.D.; Skora, A.D.; Luber, B.S.; Azad, N.S.; Laheru, D.; et al. PD-1 blockade in tumors with mismatch-repair deficiency. N. Engl. J. Med. 2015, 372, 2509-2520. [CrossRef]

115. Overman, M.J.; McDermott, R.; Leach, J.L.; Lonardi, S.; Lenz, H.J.; Morse, M.A.; Desai, J.; Hill, A.; Axelson, M.; Moss, R.A.; et al. Nivolumab in patients with metastatic DNA mismatch repair-deficient or microsatellite instability-high colorectal cancer (CheckMate 142): An open-label, multicentre, phase 2 study. Lancet Oncol. 2017, 18, 1182-1191. [CrossRef]

116. Overman, M.J.; Lonardi, S.; Wong, K.Y.M.; Lenz, H.J.; Gelsomino, F.; Aglietta, M.; Morse, M.A.; Van Cutsem, E.; McDermott, R.; Hill, A.; et al. Durable clinical benefit with nivolumab plus ipilimumab in DNA mismatch repair-deficient/microsatellite instability-high metastatic colorectal cancer. J. Clin. Oncol. 2018, 36, 773-779. [CrossRef] 
117. Lenz, H.-J.J.; Van Cutsem, E.; Limon, M.L.; Wong, K.Y.; Hendlisz, A.; Aglietta, M.; Garcia-Alfonso, P.; Neyns, B.; Luppi, G.; Cardin, D.; et al. Durable clinical benefit with nivolumab (NIVO) plus low-dose ililimumab (IPI) as first-line therapy in micro satellite instability-high/mismatch repair deficient (MSI-H/dMMR) metastatic colorectal cancer (mCRC). Ann. Oncol. 2019, 29, 714.

118. Pelster, M.S.; Amaria, R.N. Combined targeted therapy and immunotherapy in melanoma: A review of the impact on the tumor microenvironment and outcomes of early clinical trials. Adv. Med. Oncol. 2019, 11. [CrossRef] [PubMed]

(C) 2019 by the authors. Licensee MDPI, Basel, Switzerland. This article is an open access article distributed under the terms and conditions of the Creative Commons Attribution (CC BY) license (http://creativecommons.org/licenses/by/4.0/). 